\title{
Eksplorasi Penerapan Pembelajaran Tatap Muka Terbatas pada Jenjang PAUD di Masa Kebiasaan Baru
}

\author{
Mujlauwidzatul Husna ${ }^{1 凶}$, Sugito $^{1}$ \\ Pendidikan Anak Usia Dini, Universitas Negeri Yogyakarta, Indonesia(1) \\ DOI: $10.31004 /$ obsesi.v6i3.1814
}

\begin{abstract}
Abstrak
Pandemi Covid-19 membuat cara belajar di sekolah berubah. Setelah sempat kurang lebih selama satu tahun pembelajaran dilakukan jarak jauh, saat ini terbit kebijakan dari empat Menteri untuk membuka sekolah dan melaksanakan pembelajaran tatap muka terbatas di Indonesia. Tujuan dari penelitian ini adalah untuk mengetahui kesiapan hingga pelaksanaan pembelajaran tatap muka terbatas di Pendidikan Anak Usia Dini. Subjek penelitian dipilih menggunakan Teknik pusposive sampling yaitu empat sekolah di Kota Malang yang telah menerapkan pembelajaran tatap muka terbatas namun memiliki karakteristik lingkungan dan jumlah siswa yang berbeda. Teknik pengumpulan data akan dilakukan melalui studi dokumentasi dan wawancara dengan pihak sekolah. Teknik analisis menggunakan teknik analisis domain. Hasil menggambarkan bahwa persiapan yang matang dan pelaksanaan yang tertib serta Kerjasama Lembaga PAUD dan orang tua dalam melaksanakan Pembelajaran tatap Muka Terbatas menjadikan pembelajaran berjalan dengan baik dan lancar.
\end{abstract}

Kata Kunci: pembelajaran tatap muka terbatas; kebiasaan baru; paud.

\begin{abstract}
The Covid-19 pandemic has changed the way we learn in schools. After approximately one year of distance learning, four Ministers have now issued a policy to open schools and implement limited face-to-face learning in Indonesia. The purpose of this study was to determine the readiness to the implementation of limited face-to-face learning in Early Childhood Education. The research subjects were selected using the purposive sampling technique, namely four schools in Malang City that have implemented limited face-to-face learning but have different environmental characteristics and number of students. Data collection techniques will be carried out through documentation studies and interviews with the school. The analysis technique uses domain analysis techniques. The results illustrate that careful preparation and orderly implementation as well as the cooperation of PAUD Institutions and parents in implementing Limited Face-to-face Learning make learning run well and smoothly.
\end{abstract}

Keywords: limited face-to-face learning; new normal; ece.

Copyright (c) 2021 Mujlauwidzatul Husna, Sugito

$\triangle$ Corresponding author :

Email Address : mujlauwidzatu1030@gmail.com (Yogyakarta, Indonesia)

Received 21 July 2021, Accepted 2 November 2021, Published 6 November 2021 


\section{PENDAHULUAN}

Pandemi Covid-19 sudah berlangsung di Indonesia sejak awal 2020 hingga saat ini dan menjadikan berbagai kebiasaan dalam dunia pendidikan di Indonesia berubah. Kegiatan Belajar Mengajar (KBM) sebelum pandemi secara umum dilakukan di sekolah menggunakan berbagai fasilitas dan sumber belajar yang tersedia di sekolah. Seluruh siswa dan guru dapat bertemu secara tatap muka setiap hari aktif dalam seminggu. Namun, setelah datang pandemi Covid-19, pertemuan tersebut tidak bisa dilakukan di sekolah. Menteri Pendidikan dan Kebudayaan menetapkan kebijakan Pendidikan dalam masa darurat penyebaran Covid-19 yaitu salah satunya tentang perubahan proses pembelajaran dari tatap muka menjadi Pembelajaran Jarak Jauh (PJJ) dengan memenuhi ketentuan-ketentuan tertentu (Kemdikbud RI, 2020).

Perubahan KBM menuntut seluruh pelaku pendidikan menyesuaikan diri. Penyesuaian KBM di setiap sekolah mempertimbangkan ketersediaan fasilitas dan sumber daya yang ada. Selain kemampuan sekolah, KBM yang dilaksanakan jarak jauh membuat para siswa yang biasanya ke sekolah harus belajar di rumah bersama orang tua, sehingga kemampuan orang tua dalam mendukung pembelajaran juga dipertimbangkan. Ketika siswa harus belajar dari rumah dan tidak dapat secara lansgung bertemu guru di sekolah, maka PJJ tersebut dilakukan secara online walaupun dengan keterbatasan Sumber Daya Manusia (SDM) baik guru maupun orang tua dan siswa dalam menggunakan teknologi (Dayal \& Tiko, 2020). Alur penerapan pembelajaran di masa pandemi berdasarkan hasil penelitian di Lombok Timur terdiri dari penugasan, kunjungan rumah, dan laporan kegiatan harian (Nahdi et al., 2020). Sesuai dengan kemampuan stakeholder dalam dunia pendidikan, PJJ untuk Taman Kanak-kanak (TK) di Aceh ada yang dapat dilaksanakan secara online melalui media WhatsApp dan permainan online, tetapi juga terdapat sekolah dengan ekonomi orang tua menengah ke bawah yang harus mengambil dan mengumpulkan tugas ke sekolah setiap pekan (Fitri \& Abdul Latif, 2021).

Penutupan sekolah dan pengalihan metode belajar menjadi PJJ tidak dinilai signifikan dalam menekan penyebaran Covid-19. Hal yang perlu diperketat adalah aturan untuk mematuhi protokol kesehatan seperti memakai masker dan menjaga jarak. Penutupan sekolah diprediksi hanya akan mencegah $2-4 \%$ kematian, jauh lebih sedikit daripada intervensi jarak sosial lainnya (Viner et al., 2020). Jarak sosial saja, sudah cukup untuk mengendalikan Covid19, penutupan sekolah proaktif tidak dapat menghentikan penularan sendiri, mereka dapat mengurangi insiden puncak sebesar 40-60\% dan menunda epidemi (Zhang et al., 2020). Metode PJJ justru dirasa hampir semua jenjang pendidikan termasuk PAUD merupakan metode yang sulit karena berbagai keterbatasan.

Selama satu tahun berlangsung, PJJ pada jenjang PAUD menemui berbagai kendala. Kendala tersebut berasal dari guru maupun orang tua di antaranya yaitu fasilitas yang tidak memadai untuk PJJ (Ayuni et al., 2021; Satrianingrum \& Prasetyo, 2021; Wardani \& Ayriza, 2021), biaya untuk membeli paket data serta sinyal yang terbatas (Agustin et al., 2021; Ayuni et al., 2021; Satrianingrum \& Prasetyo, 2021; Wardani \& Ayriza, 2021), guru sulit mengembangkan kegiatan dan menyampaikannya pada anak (Agustin et al., 2021; Ayuni et al., 2021; Satrianingrum \& Prasetyo, 2021). Orang tua juga memiliki kendala tersendiri dalam menggantikan peran guru di rumah, yaitu kesulitan membagi waktu, pengaturan emosi dalam menghadapi anak, hingga pemahaman orang tua yang kurang terhadap materi atau tugas dari guru untuk anak (Ayuni et al., 2021; Satrianingrum \& Prasetyo, 2021).

Kesiapan pihak sekolah maupun orangtua dalam melaksanakan PJJ masih perlu ditingkatkan walaupun prosesnya telah berjalan selama satu tahun. Transisi metode pembelajaran yang mendadak membuat banyak hal harus disesuaikan dengan cepat. Penyesuaian perubahan dalam metode PJJ harus dilakukan oleh berbagai pihak seperti sekolah, orang tua, masyarakat maupun sisiwa sendiri. Kerjasama antar berbagai pihak menjadi hal penting dalam PJJ di tengah permasalahan-permasalahan lain yang dihadapi masing-masing pihak tersebut. Kendala yang telah banyak diteliti ketika PJJ telah mengubah 
strategi pembelajaran, sehingga dukungan dari rekan kerja, orang tua, kepala sekolah, dan sekolah sangat penting untuk melanjutkan pelaksanaan pembelajaran secara tertib (Rasmitadila et al., 2020).

Perubahan yang banyak terjadi dalam dunia pendidikan di masa pandemi Covid-19 bukan hanya dari segi metode pembelajaran saja, tetapi juga isi kurikulumnya. Keterampilan siswa saat ini dituntut untuk dapat selalu menyesuaikan dengan perubahan dan tantangan zaman. Berbagai kendala yang dihadapai selama PJJ menyadarkan bahwa pendidikan di Indonesia belum fleksibel untuk mengikuti perkembangan zaman. Penyesuaikan dengan era digital yang telah dilakukan mengalami akselerasi ketika pandemi Covid-19 datang. Kondisi saat ini memaksa pendidikan lebih memanfaatkan teknologi, perkembangan yang sudah berjalan, di dorong oleh komersialisme dan ideologi pasar yang berkuasa (Pacheco, 2020).

Kebijakan untuk kembali melakukan pembelajaran tatap muka mulai diberlakukan mengingat penyesuaian yang sulit dan berbagai kendala lain yang terjadi selama PJJ di PAUD mengakibatkan pembelajaran belum efektif (Nurdin \& Anhusadar, 2021). Berbagai aspek perkembangan anak menurun secara beragam sesuai kondisi setiap keluarga. Orang tua masih dapat membantu perkembangan kognitif anak, tetapi kesulitan mengkondisikan keadaan psikologis satu sama lain. Temuan di Surakarta menunjukkan bahwa penurunan paling banyak yaitu pada aspek sosial emosional (Wulandari \& Purwanta, 2021). Orang tua dengan rutinitas baru menemani secara penuh pembelajaran anak menggantikan tugas guru cenderung tidak sabar hingga menimbulkan kekesalan dan melampiaskannya kepada anak (Wardani \& Ayriza, 2021).

Seiring dengan berjalannya waktu serta pemberian vaksin yang telah berjalan, kebijakan pembelajaran tatap muka telah ditetapkan untuk dibuka serentak mulai tahun pelajaran 2021/2022. Kebijakan ini tertuang dalam Surat Keputusan Bersama (SKB) empat menteri yaitu Menteri Pendidikan dan Kebudayaan, Menteri Agama, Menteri Kesehatan, dan Menteri Dalam Negeri. Kebijakan tersebut salah satunya yaitu memberi pilihan sekolah untuk melaksanakan pembelajaran tatap muka terbatas dengan menerapkan protokol kesehatan ketat atau melakukan pembelajaran jarak jauh. Selain itu, orang tua memiliki wewenang untuk mengizinkan anaknya melakukan pembelajaran tatap muka terbatas atau pembelajaran jarak jauh (Kemdikbud RI, 2020).

Sehubungan dengan mulainya pembelajaran tatap muka terbatas, penelitian ini akan mendeskripsikan pelaksanaan pembelajarannya di sekolah dengan karakteristik lingkungan dan jumlah peserta didik yang beragam. Tujuan dari penelitian ini adalah memaparkan kesiapan sekolahhingga proses pelaksanaan pembelajaran tatap muka terbatas PAUD di Kota Malang. PAUD yang menjadi sasaran penelitian ini adalah empat PAUD yang telah menerapkan Pembelajaran Tatap Muka Terbatas (PTMT) tahun 2021.

\section{METODOLOGI}

Penelitian ini menggunakan metode penelitian kualitatif. Penelitian kualitatif adalah metode yang berlandaskan pada filsafat postpositivisme, digunakan untuk meneliti kondisi obyek secara alamiah (Sugiyono, 2019). Penelitian ini fokus pada satu fenomena yang dipelajari sebagai suatu kasus. Peneliti kualitatif menjadi instrumen utama, namun selanjutnya akan dikembangkan instrumen penelitian sederhana yang diharapkan dapat melengkapi data. Dalam hal ini peneliti menganalisis fenomena penerapan pembelajaran tatap muka terbatas di Kota Malang yang secara resmi telah mengizinkan sekolah melakukan pembelajaran tatap muka terbatas pada masa kebiasaan baru sejak April 2021.

Subyek dalam penelitian ini dipilih menggunakan teknik purposive sampling di mana pengambilan sampel berdasarkan pertimbangan tertentu (Sugiyono, 2019). Peneliti memilih 4 Lembaga PAUD di Kota Malang sebagai subyek penelitian ini. Lembaga pertama adalah KB dan TK Al Fadholi (AF) dengan jumlah siswa lebih dari 100 dan berlokasi di lingkungan yang ramai. Kedua, PAUD KB dan TK Al Ghoniya (AG) dengan jumlah siswa lebih dari 100 tapi berlokasi jauh dari keramaian. Ketiga, TK Aisyiyah Bustanul Athfal 37 (AB) dengan jumlah 
siswa kurang dari 50 dan berlokasi cukup jauh dari keramaian. Terakhir yaitu TK Wahid Hasyim yang memiliki siswa kurang dari 50 dan satu lokasi dengan beberapa sekolah dengan jenjang yang lebih tinggi. Selengkapnya dapat dilihat pada tabel 1.

Tabel 1. Profil Responden

\begin{tabular}{cccc}
\hline Inisial & $\begin{array}{c}\text { Jumlah } \\
\text { Pendidik }\end{array}$ & $\begin{array}{c}\text { Jumlah } \\
\text { Siswa }\end{array}$ & Keterangan \\
\hline AF & 10 & 142 & Satu lokasi dengan pesantren AF \\
AG & 13 & 142 & - \\
AB & 4 & 23 & - \\
WH & 5 & 33 & Satu lokasi dengan SD dan SMP WH \\
\hline
\end{tabular}

Penelitian dilakukan pada Bulan Juni 2021 ketika sekolah telah menerapkan Pembelajaran Tatap Muka Terbatas (PTMT) minimal selama satu bulan. Teknik pengumpulan data yang digunakan adalah wawancara kepada kepala sekolah atau staf kependidikan dan studi dokumentasi berupa empat video persiapan pembelajaran tatap muka terbatas. Informasi tentang penerapan PTMT digali melalui wawancara dengan pertanyaan yang disusun berdasarkan standar PTMT dalam SBK Empat Menteri dan pertanyaan tambahan dari hasil studi dokumentasi yang telah dilakukan sebelum wawancara. Data dianalisis menggunakan teknik analisis domain yaitu menganalisis gambaran objek penelitian secara umum atau di tingkat permukaan, namun relatif utuh tentang objek penelitian tersebut (Putra, 2014). Desain penelitian dapat dilihat pada gambar 1.

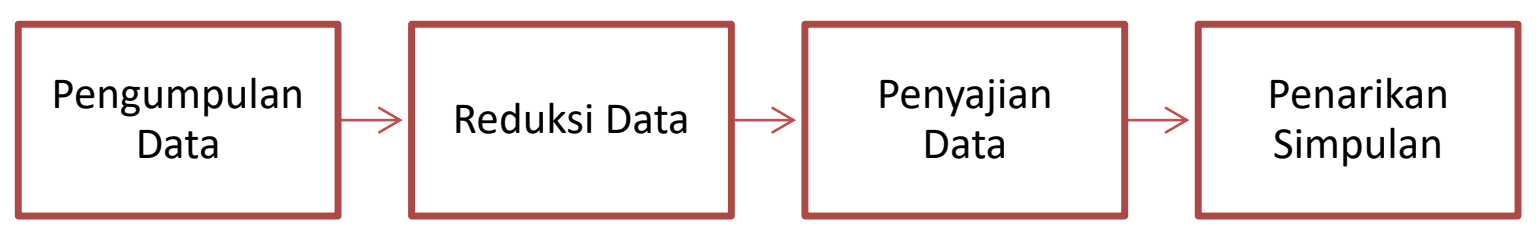

Gambar 1. Langkah-langkah penelitian

\section{HASIL DAN PEMBAHASAN}

Lingkungan sekolah sudah satu tahun sepi oleh kegiatan belajar mengajar maupun ekstrakulikuler. Pertemuan guru dan siswa terbatas pada layar hingga kebijakan pembelajaran tatap muka terbatas terbit. Kebijakan ini diambil dengan segala pertimbangan karena begitu banyak kendala yang dialami guru maupun siswa dalam melaksanakaan pembelajaran online, terutama untuk jenjang PAUD. Anak-anak usia dini memiliki kemungkinan paling kecil untuk terpapar Covid-19 daripada orang dewasa, selain itu juga paling banyak dirugikan dalam pembelajaran di luar sekolah (Munro \& Faust, 2021; Spaull, 2020). Oleh karena itu, pembelajaran tatap muka yang dilakukan setelah sekian lama online dengan pembatasan sehingga disebut sebagai Pembelajaran Tatap Muka Terbatas (PTMT).

Penelitian ini memaparkan informasi penerapan PTMT yang telah dilakukan 4 lembaga PAUD di Kota Malang antara Bulan April hingga Juni 2021 (sekitar 1-2 bulan). Lembaga yang telah menerapkan PTMT ini menjelasakan penerapan mulai dari persiapan, pelaksanaaan hingga evaluasi yang dapat dijadikan bahan dalam mempersiapkan PTMT di tahun pelajaran baru.

\section{Persiapan Pembelajaran Tatap Muka Terbatas}

Adaptasi dalam berbagai aspek kehidupan terus dilakukan sepanjang pandemi hingga saat ini. Pendidikan merupakan salah satu aspek penting yang perlu mendapat perhatian khusus karena masa depan sebuah bangsa ditentukan oleh kualitas generasi penerusnya yang dipersiapkan melalui Pendidikan. Berinfestasi pada kesehatan, pendidikan dan perkembangan anak yang merupakan generasi penerus bermanfaat sepanjang hidup anak, 
untuk masa depan mereka, dan masyarakat secara keseluruhan (Clark et al., 2020). Pembelajaran online menjadi solusi ketika angka covid masih sangat tinggi. Kini menuju ke pembelajaran tatap muka, sekolah perlu persiapan yang matang karena pembelajaran tatap muka saat ini harus berdampingan dengan covid.

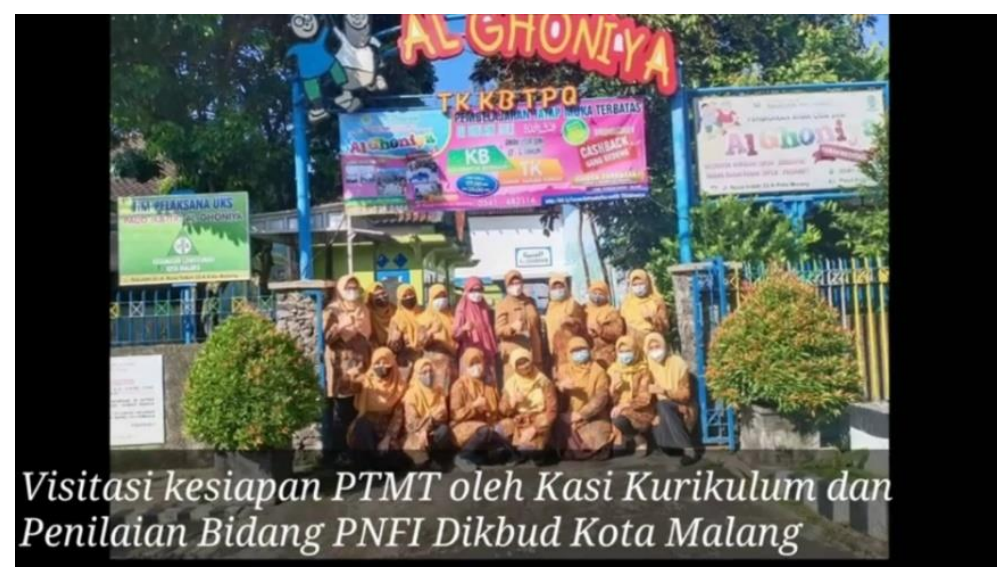

\section{Gambar 2. Monitoring Kesiapan PTMT di TK AG}

...dari dinas Pendidikan Kota malang menurut SK Walikota no 15 itu tentang PTMT yang dilaksanakan semua sekolah baik negeri maupun swasta Kota malang, AG termasuk salah satu pilot project untuk jenjang PAUD. Selama uji coba 2 minggu melaksanakan PTMT, setelah itu ada pelaporan berupa video rangkuman setiap hari. Itu yang menvideokan adalah orang tua, ada juga video per hari di Instagram itu semua hasil karya orang tua..." (AG)

...setelah batal PTMT akhir tahun 2020, pada April 2021 ada monitoring dari dinas untuk memastikan kesiapan melaksanakan PTMT dari segi fasilitas dan lain-lain. Kemudian mulai kami laksanakan PTMT pada tanggal 19 April 2021... (AF)

Dinas Pendidikan Kota malang telah mengeluarkan Surat Keputusan yang menerangkan bahwa PTMT sudah dapat dilakukan di wilayah Kota Malang sejak April 2021. Persiapan setiap sekolah dinilai dan dimonitoring oleh dinas untuk memastikan bahwa Lembaga yang bersangkutan telah memenuhi protokol kesehatan sesuai standar pemerintah. Sebelum sekolah mempersiapkan lingkungan lembaga dan seluruh orang yang terlibat dalam PTMT, dinas melakukan sosialisasi kepada seluruh kepala sekolah termasuk kepala sekolah pada jenjang PAUD. Sekolah membutuhkan arahan dan dukungan yang jelas untuk meningkatkan jam mengajar dan memperkenalkan cara untuk memulihkan kualitas pembelajaran selama masa pembelajaran online (Sparrow et al., 2020).

.... kami mengundang orang tua untuk sosialisasi melalui zoom kemudian saya menunjukkan foto-foto fasilitas protokol kesehatan di sekolah. Dan juga video untuk dilihat anak nanti bagaimana kedaatangan, pembelajaran di kelas hingga pulang sekolah. Jadi anak-anak melihat video simulasi terlebih dahulu sebelum PTMT, tentunya dengan bantuan pengertian dari wali siswa... (kutipan wawancara dengan TK AF)

Menindaklanjuti surat keputusan dinas, pihak sekolah mempersiapkan Lembaga untuk melakukan PTMT dan juga melakukan sosialisasi kepada wali siswa. Sosialisasi ini dilakukan keempat sekolah melalui zoom dan untuk WH mengundang orang tua ke sekolah dengan tetap mengindahkan protokol kesehatan. Selain itu, wali siswa diminta persetujuan satu per satu terkait izin untuk anaknya mengikuti PTMT di sekolah menggunakan bantuan google form. Hasil yang diperoleh dari wali siswa sebagian besar mengizinkan anak-anaknya 
mengikuti PTMT, walaupun beberapa masih belum mengizinkan. Gambaran hasil angket dapat dilihat pada gambar 3 .

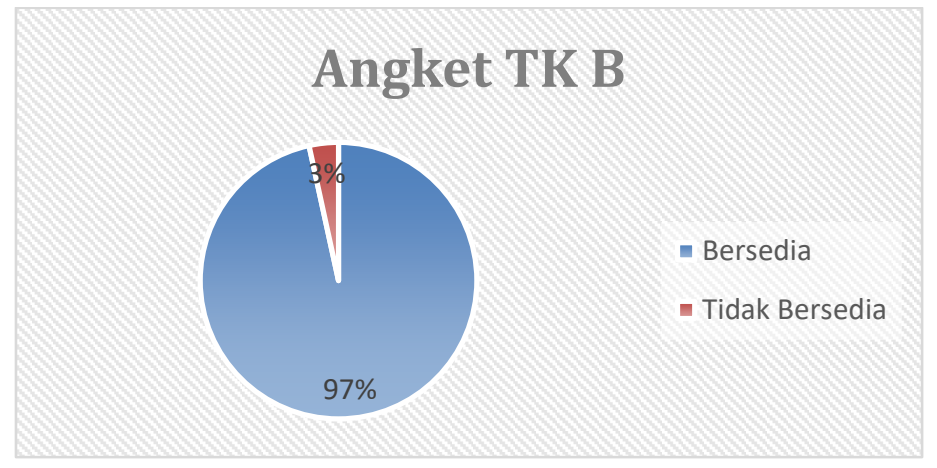

Gambar 3. Hasil angket persetujuan orang tua di TK AG

Ketika pembelajaran selama pandemi dilakukan secara jarak jauh, peran orang tua dan kerjasamanya dengan guru menjadi lebih penting dari sebelumnya. Hal ini dikarenakan belum ada persiapan sebelumnya untuk menghadapi situasi belajar seperti yang terjadi selama pandemi, sehingga butuh usaha lebih keras dalam penyesuaiannya. Dilihat dari sudut pandang orang tua dan siswa, PJJ menjadi sebuah tantangan bahkan membebani orang tua (Misirli \& Ergulec, 2021). Orang tua sebagai pendamping belajar anak di rumah selama PJJ yang mengalami berbagai kendala telah terbukti mengharapkan anak-anak segera kembali ke sekolah dan belajar bersama guru secara langsung.

Pembukaan kembali sekolah diharapkan dapat membantu siswa yang banyak mengalami kendala ketika PJJ. Meskipun demikian, banyak pertimbangan dan persiapan yang diperlukan sebelum benar-benar membuka sekolah untuk anak-anak belajar pada masa kenormalan baru. Untuk mencapai target pembelajaran dalam PTMT perlu ditunjang beberapa faktor seperti kesiapan sarana prasarana, metode pembelajaran, hingga pengkondisian warga sekolah dalam beradaptasi di sekolah (Tanuwijaya \& Tambunan, 2021).

PTMT yang diterapkan pihak sekolah memberlakukan aturan-aturan tertentu termasuk kaitannya dengan jumlah siswa yang sebagian besar telah mendapat izin orang tua. Pengaturan jadwal masuk anak-anak setiap harinya yaitu dikurangi sebanyak $50 \%$. Setiap sekolah memiliki kewenangan masing-masing dalam mengatur jadwal masuk anak-anak. Jadwal di TK AF untuk setiap anak sebanyak 2 kali dalam satu pekan dengan durasi 1,5 jam. di TK AG setiap anak hanya masuk 1 kali dalam semingu selama 2 jam. Pembelajaran di TK WH dilakukan dengan membagi 2 kapasitas kelas dan durasi waktu setiap harinya selama 2,5 jam. Begitu juga TK AB mengalami pengurangan jam pelajaran dan beban belajar siswa dibandingkan kondisi normal.

Siswa yang tidak mendapat jadwal masuk atau memang tidak mendapat izin orang tua untuk mengikuti PTMT tetap dapat belajar secara online atau jarak jauh. Proses pembelajaran ini dapat dikatakan blended learning. Meskipun pembelajaran dapat dilakukan secara tatap muka, tetapi masih terbatas dan perlu penyesuaian dengan segala sarana sehingga diambil alternatif pembelajaran jarak jauh sekaligus tatap muka.

Masa kebiasaan baru suatu saat akan menjadi kebiasaan lama atau rutinitas. Pengalaman baru ketika PJJ setidaknya memberi pengetahuan dan kompetensi di bidang teknologi. Dunia yang telah masuk pada era digital sudah semestinya diikuti dengan sumber daya manusia yang memiliki kompetensi memadai. Kebiasaan baru juga terjadi dalam proses pembelajaran di mana teknologi lebih diberdayakan. Sebuah penelitian memaparkan keberhasilan pembelajaran menggunakan teknologi dan tatap muka sebagai model yang sukses dalam berbagai contoh integrasi dalam sistem pendidikan (Alam \& Agarwal, 2020). Pembelajaran blended learning yang mulai diterapkan secara luas di Indonesia diharapkan dapat memberi banyak dampak positif pada capaian belajar siswa. 


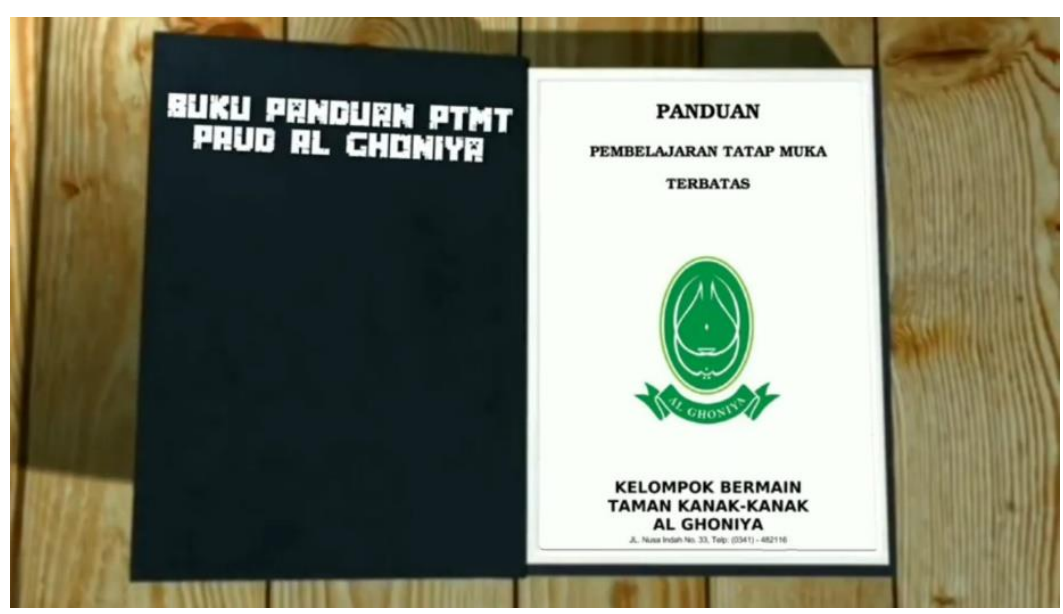

Gambar 4. Buku Panduan PTMT TK AG

Persiapan yang dilakukan untuk menyongsong PTMT dilengkapi dari berbagai faktor. Mempersiapkan guru, siswa, orang tua dan juga sekolah sendiri dilakukan sebelum menerapkan PTMT. Sekolah AF, AG, AB dan WH juga melakukan berbagai persiapan untuk melaksanakan PTMT. Guru-guru di Kota Malang telah mendapatkan dua kali vaksinasi dan terus memantau kesehatannya. Selain itu, fasilitas di setiap sekolah dilengkapi dengan protokol kesehatan lengkap dan mempersiapkan skenario pembelajaran baru bersama anakanak di sekolah.

...persiapan yang dilakukan yaitu menyusun meja berjarak sesuai dengan jumlah anak yang akan masuk yaitu 4 anak dalam satu kelas setiap harinya. Selain itu menginfokan ke wali murid jika PTM yang akan dilakukan di sekolah sudah sesuai protokol kesehatan dan SOP yang telah dibuat." $(A B)$

...kami mempersiapkan handsanitizer, masker, disinfektan, standing thermometer, thermogun, sabun cuci tangan, wastafel, hingga face shield untuk guru."(WH)

...orang tua sangat mendukung pembelajaran tatap muka. Satgas Covid-19 yang terbentuk beranggotakan komite. Mereka memantau dan mengetahui langsung pelaksanaan PTMT, jadi orang tua memilikikepercayan kepada sekolah..."(AG)

Tidak berhenti pada fasilitas dan pengaturan jadwal, seluruh sekolah yang menjadi responden menerangkan bahwa mereka melakukan pendataan terkait perjalanan siswa dan kondisi keluarga yang tinggal satu atap dengan anak. Menerapkan praktik pengendalian infeksi dengan mengendalikan sumber infeksi, memblokir rute penularan, dan perlindungan populasi rentan sangat penting (Shen et al., 2020). Anak-anak dihimbau untuk tidak melakukan perjalanan ke luar kota atau jika memang dibutuhkan maka sepulang dari luar kota dipersilakan isolasi mandiri di rumah dan menjalani online sementara waktu. Orang tua juga wajib melaporkan jika terdapat anggota keluarga yang sakit di rumah. Pendataan ini dilakukan sebelum melaksanakan PTMT dan berlanjut ketika PTMT dilaksanakan.

...kami pihak sekolah mendata langsung ke rumah wali murid yang sudah memberi izin PTM. Kan kami juga mensosialisasikan agar tidak bepergian ke luar kota dulu atau jika ada maka kami tidak mengizinkan mereka masuk sekolah dahulu... (AB)

...ketika sosialisasi di awal, kami sudah membuat kesepakatan dengan orang tua untuk tidak mengajak anak bepergian atau nanti ketika Kembali dipersilakan karantina dulu. Orang tua juga wajib lapor jika ada anggota keluarga yang sakit... (AF) 
Mengingat kebiasaan PTMT masih baru, pihak sekolah dan orang tua masih selalu berusaha dalam beradaptasi. Sekolah membutuhkan arahan dan dukungan yang jelas untuk meningkatkan jam mengajar dan memperkenalkan cara untuk memulihkan kehilangan pembelajaran yang sempat terjadi ketika PJJ (Sparrow et al., 2020). Pihak sekolah berusaha menekan penyebaran virus di lingkungan sekolah, salah satunya dengan selalu membersihkan alat main setelah digunakan dan menyemprotkan disinfektan secara berkala. Berbagai persiapan yang telah disiapkan tidak dapat berhenti begitu saja melainkan perlu terus dievaluasi dan ditingkatkan sesuai dengan kebutuhan. Dukungan dari berbagai kalangan diperlukan untuk mendukung kesuksesan pembelajaran di masa kebiasaan baru. Contohnya seperti orang tua perlu memberikan pengertian tentang kesehatan, kebersihan serta protokol kesehatan kepada anak untuk menguatkan pondasi anak dalam beradaptasi.

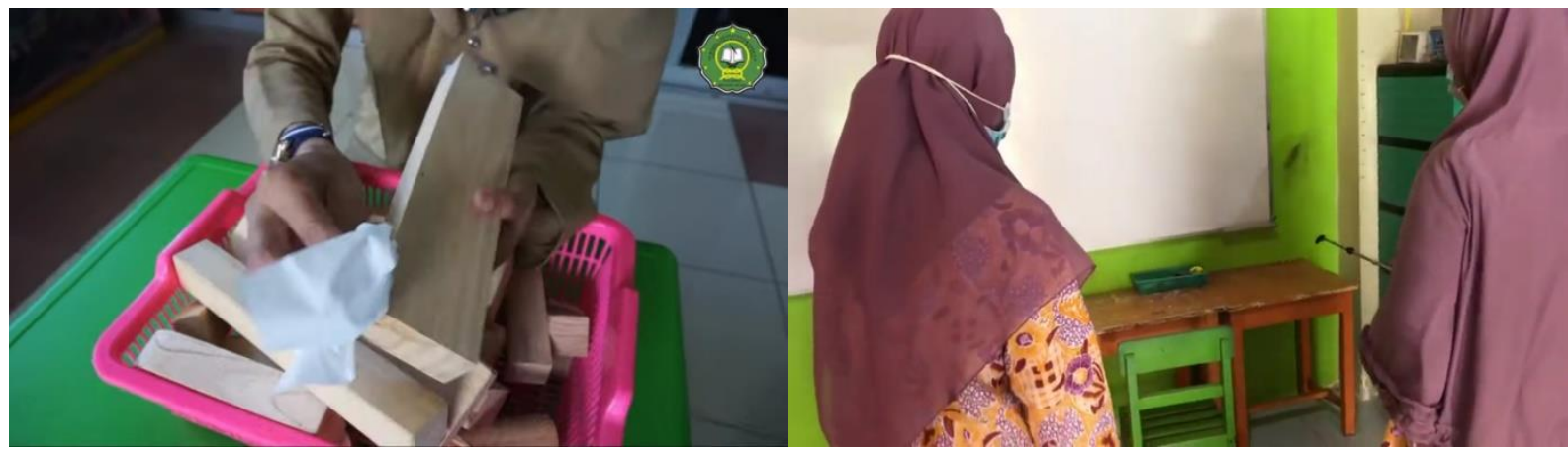

Gambar 5. Membersihkan alat main dan lingkungan belajar anak

\section{Pelaksanaan Pembelajaran Tatap Muka Terbatas}

Tantangan dalam PTMT adalah ketika pelaksanaannya. Penelitian yang dilakukan ketika masa pandemi flu babi beberapa tahun silam menghasilkan temuan tentang jumlah kontak murid ketika masa sekolah rata-rata 18,51 kontak setiap hari sedangkan 9,24 kontak terjadi ketika liburan semester (Eames et al., 2010). Perbedaan jumlah kontak yang signifikan memberi gambaran pada masa pandemi saat ini agar dipersiapkan dan dilaksanakan dengan lebih ketat. Pertimbangan berbagai hal tetap mencoba melaksanakan pembelajaran tatap muka dengan peraturan ketat dan terperinci.

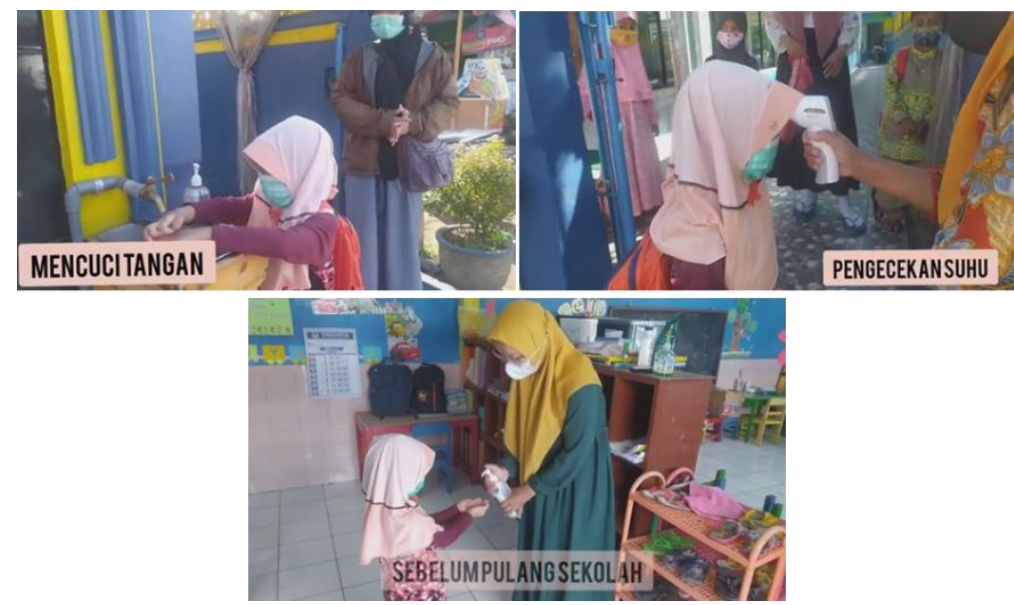

Gambar 6. Protokol kesehatan ketika siswa datang

Berdasarkan studi dokumentasi, prosedur kedatangan di TK AF, TK AG, TK AB maupun TK WH relatif sama. Anak datang menggunakan masker dan diantar pada jarak yang telah ditetapkan sekolah. Guru berjaga di beberapa titik untuk memastikan anak-anak mematuhi protokol kesehatan dan SOP yang berlaku. Kedatangan anak setiap paginya 
disambut oleh guru tanpa ada sentuhan tangan. Selanjutnya anak diukur suhu tubuh dan dicatat untuk memantau status kesehatan anak. Anak berbaris di atas tanda khusus untuk menunggu giliran. Setelah itu mencuci tangan menggunakan sabun dan air mengalir, mengeringkannya dan menuju ke kelas masing-masing tanpa bermain di halaman sekolah. Langkah-langkah tersebut merupakan langkah untuk memblokir rute penularan virus yaitu mencegah penularan melalui kontak pernapasan, menghindari transportasi umum, dan pemantauan kesehatan anak (Shen et al., 2020).

Pelaksanaan PTMT di TK AF, TK AG, TK AB, dan TK WH memperlihatkan anak-anak yang datang dan tertib mengikuti arahan guru di setiap pos yang dijaga guru. Anak-anak terlihat mandiri dan siap dengan kebiasaan baru PTMT. Terlihat juga dalam video kegembiraan anak-anak dapat kembali belajar di sekolah meskipun dengan segala hal baru yang diterapkan ketika PTMT.

...anak-anak bisa tertib karena sebelumnya sudah disosialisasikan. Orang tua juga pasti memberi pengertian di rumah sebelum berangkat ke sekolah... (AF)

Kegiatan Belajar Mengajar (KBM) dibagi menjadi KBM secara online dan PTMT atau blended learning. Blended learning merupakan solusi alternatif untuk menanggulangi kelemahan-kelemahan PJJ dan PTM untuk menghsilkan rangkaian pembelajaran yang efektif, efisien, dan menyenangkan bagi siswa dengan tidak tidak membuang teori-teori pembelajaran lama (Abdullah, 2018). KBM secara online menjadi alternatif bagi siswa yang tidak terjadwal datang ke sekolah maupun siswa yang tidak mendapat persetujuan orang tua untuk mengikuti PTMT. Sedangkan siswa yang mendapatkan izin mengikuti PTMT, belajar secara tatap muka bersama guru dan teman-teman di sekolah.

KBM di sekolah didesain guru agar mengurangi interaksi antar siswa. Peralatan bermain hanya dipakai satu anak dan tidak bisa bergantian. Tempat duduk anak juga telah diberi nama agar anak tidak berpindah-pindah. Waktu pembelajaran yang dikurangi telah menghilangkan waktu istirahat atau bermain bebas sehingga anak-anak tidak berkerumun untuk bermain bersama. Di TK AF dan AG juga menghilangkan jam makan kue yang biasanya dilakukan setelah kegiatan inti. Siswa juga pulang lebih awal dan memastikan orang tua atau pengasuh menjemput tepat waktu.

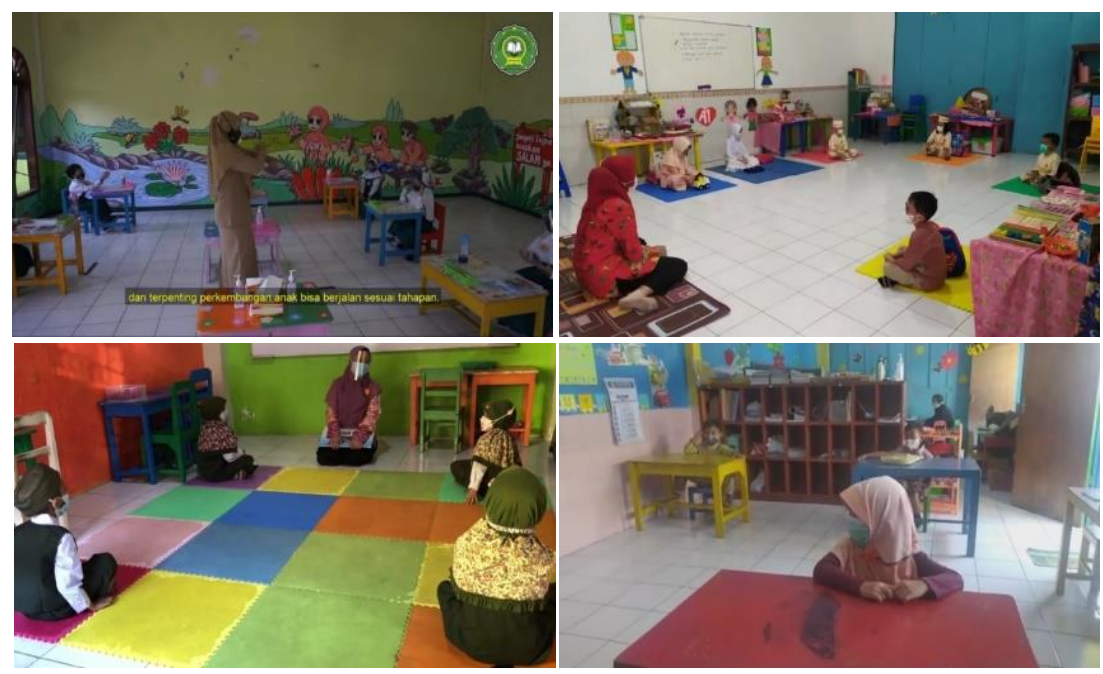

Gambar 7. Kegiatan Belajar Mengajar (KBM) di dalam kelas

Hal yang tetap dimaksimalkan demi capaian pembelajaran yang diinginkan adalah memaksimalkan penyampaian materi kepada siswa. Jumlah siswa yang lebih sedikit dari jumlah normal semestinya memudahkan guru dalam memantau tiap perkembangan anak. Capaian siswa maksimal apabila dilakukan optimalisasi sekolah tatap muka dengan 
mengutamakan keseimbangan pertumbuhan dan perkembangan siswa yang didukung dengan efektivitas penyampaian materi mata bagi siswa (Meriana \& Tambunan, 2021). Materi pembelajaran selama PTMT dikurangi termasuk kegiatan belajar yang dikerjakan siswa. Jumlah kegiatan yang biasanya berjumlah 4-5 kegiatan berkurang menjadi 1-2 kegiatan saja dalam satu hari. Gambaran kondisi kegiatan belajar mengajar di dalam kelas dapat dilihat pada gambar 7.

\section{Evaluasi Pembelajaran Tatap Muka Terbatas}

Kedisiplinan dalam mematuhi protokol kesehatan guru disoroti oleh siswa dan wali siswa. Guru menjadi teladan siswa terutama dalam mematuhi protokol kesehatan di masa kebiasaan baru seperti saat ini. Guru harus tegas dalam menegakkan aturan sehingga anak juga akan terbiasa mematuhi aturan tersebut. AUD yang mendapatkan arahan yang tepat dan memiliki konsep yang matang akan mudah dalam menyesuaikan diri dengan PTMT. Sebuah penelitian yang dilakukan di salah satu PAUD di Semarang menjelaskan alur siswa dalam menyesuaikan diri yaitu mulai dari anak didampingi secara penuh oleh guru hingga anak bisa mandiri dan kemudian terbiasa dengan kebiasaan pada masa kenormalan baru (Supriyanto \& Rozaq, 2021).

...hari pertama itu sangat penting. Saya menghimbau semua guru untuk tertib dan disiplin karena kalau di hari pertama sudah kendor, anak-anak besok-besok juga sulit untuk diarahkan... $(A F)$

Beberapa anak khususnya anak tingkat TK A masih memerlukan waktu penyesuaian lebih banyak untuk masuk sekolah dengan kebiasaan baru. Kondisi anak jenjang TK A melakukan pembelajaran online sejak pertama kali menjadi siswa TK, sehingga belum pernah sama sekali masuk sekolah dan belajar bersama teman-teman dan guru secara lansgung. Selebihnya semua sekolah mengakui anak tingkat TK B dapat disiplin ketika pelaksanaan PTMT sejak hari pertama. Anak TK B pada tahun pelajaran 2020/2021 sudah mengenal guru, teman dan lingkungan sekolahnya ketika TK A karena PJJ mulai pertama kali dilakukan pada pertengahan semester genap tahun pelajaran 2019/2020 (Mendikbud, 2020).

...untuk anak TK A memang mempunyai kendala, seperti tidak mau pisah dengan orang tuanya. Ada juga yng tidak mau masuk, akan tetapi guru selalu menggunakan pendekatan untuk anak-anak yang tidak mau pisah dengan orang tua atau tidak mau masukkarena temannya sedikit... (AB)

...pertama kali masih bingung dengan peraturan yang ada sehingga guru membutuhkan tenaga ekstra untuk mendisilinkan anak-anak. tapi sejauh ini anak-anak TK A cepat menyesuaikan diri karena dari rumah sudah diberikan arahan oleh orang tua. (WH)

...kalau anak TK A awalnya terkendala belum hafal. Terkadang wajah di layer ketika online dengan aslinya berbeda, anak-anak jadi mirip-mirip. Hanya itu saja, selebihnya bisa menyesuaikan. Kalau TK B juga sudah hafal karen asetahun sebelumnya belum online... (AG)

...ada yang minta diantar orang tua hingga elas lalu mau ditinggal. Tapi kalau memang ada yang tidak mau masuk walaupun orang tua sudah mengizinkan dan telah dibujuk juga, kami perbolehkan pulang dan online saja. Ketika anak sudah siap bisa mengikuti PTMT di sekolah... $(A F)$

Penyesuaian PTMT tidak hanya dilakukan guru dan siswa, melainkan juga orang tua. Selain guru dan siswa, orang tua yang mengantar juga perlu menyesuaikan diri seperti mengantar anak sebatas depan gerbang. Kedisiplinan semua pihak dalam mematuhi protokol 
kesehatan memiliki andil dalam kelancaran PTMT. Kendala PTMT bisa muncul dari proses pembelajaran maupun penerapan protokol kesehatannya.

...kadang orang tua lebih sulit diatur, ketika biasanya mengantar anak dan bertemu wali murid lain bisa mengobrol. Sekarang harus ditertibkan untuk menghindari kerumunan... (AG)

...siswa yang tidak PTMT karena tidak mendapat izin melaksanakan online. Tapi terkadang siswanya tidak mengumpulkan tugas yang diberikan wali kelas. Tapi solusinya, guru kealsnya yang mendatangi siswa tersebut. (AB)

Kendala di tenaga guru yang harus terpecah menjadi 2 yaitu tatap muka dan video call bagi anak yang pada hari tersebut tidak mendapatkan jadwal tatap muka. (WH)

Melewati tahun pelajaran 2020/2021 dengan pembukaan PTMT di akhir semester 2 memberi pengalaman dan gambaran untuk selanjutnya melaksanakan PTMT di tahun pelajaran yang baru. Tantangan baru akan didapatkan mengingat akan ada siswa baru yang perlu menyesuaikan diri bukan hanya dengan kebiasaan baru tapi dengan lingkungan, guru dan teman-teman baru. Evaluasi menjadi hal yang penting untuk dapat meningkatkan kualitas pembelajaran di masa kenormalan baru.

\section{SIMPULAN}

PTMT menjadi solusi ketika berbagai kendala pembelajaran online selama satu tahun dirasakan guru, orang tua dan siswa. Pembelajaran berlangsung dengan penyesuaian fasilitas dan kurikulum serta metode pembelajaran. Fasilitas dilengkapi dengan standar protokol kesehatan yang telah ditetapkan pemerintah. Kurikulum disederhanakan agar tidak memberatkan siswa maupun guru mengingat berbagai pembatasan yang masih harus ditaati meskipun PTMT telah diperkenankan. Metode pembelajaran dalam jaringan tidak secara langsung melainkan menggunakan blended learning dimana pembelajaran online maupun luring tetap berlangsung. Anak Usia Dini dapat beradaptasi dengan cukup baik setelah mendapat arahan dari orang dewasa. Usaha guru dan orang tua dalam memberi pengertian anak harus disampaikan sejelas-jelasnya dan selalu dievaluasi disertai dengan membangun pemahaman anak dari awal, teladan dan pengulangan dalam menyampaikan berbagai kebiasaan baru. Keadaan lingkungan yang berbeda di setiap sekolah tidak akan menyulitkan siswa dalam beradaptasi ketika pondasi pemahaman dan pembiasaan anak telah kokoh. Para siswa di empat TK yang diteliti dapat beradaptasi dengan baik meskipun di awal masih ada beberapa anak yang butuh perhatian khusus.

\section{UCAPAN TERIMA KASIH}

Ucapan terima kasih disampaikan kepada seluruh responden yang bersedia berbagi ilmu dan pengalaman serta teman sejawat yang bersedia berdiskusi mengenai penelitian ini. Atas kesempatan mengeksplorasi dunia pendidikan khususnya di masa kebiasaan baru, ucapan terima kasih juga ditujukan kepada Prodi Magister Pendidikan Anak Usia Dini untuk kesempatan mengeksplorasi isu-isu pada dunia anak usia dini di perguruan tinggi.

\section{DAFTAR PUSTAKA}

Abdullah, W. (2018). Model Blended Learning dalam Meningkatkan Efektifitas Pembelajaran. Fikrotuna, 7(1), 855-866. https:// doi.org/10.32806/jf.v7i1.3169

Agustin, M., Puspita, R. D., Nurinten, D., \& Nafiqoh, H. (2021). Tipikal Kendala Guru PAUD dalam Mengajar pada Masa Pandemi Covid 19 dan Implikasinya. Jurnal Obsesi : Jurnal Pendidikan Anak Usia Dini, 5(1), 334. https://doi.org/10.31004/obsesi.v5i1.598

Alam, M. S., \& Agarwal, J. (2020). Adopting a Blended Learning Model in Education: Opportunities and Challenges. International Journal of Early Childhood Special Education, 12(2), 1-7. https://doi.org/10.9756/INT-JECSE/V12I2.201050 
Ayuni, D., Marini, T., Fauziddin, M., \& Pahrul, Y. (2021). Kesiapan Guru TK Menghadapi Pembelajaran Daring Masa Pandemi Covid-19. Jurnal Obsesi : Jurnal Pendidikan Anak Usia Dini, 5(1), 414. https://doi.org/10.31004/obsesi.v5i1.579

Clark, H., Coll-Seck, A. M., Banerjee, A., Peterson, S., Dalglish, S. L., Ameratunga, S., Balabanova, D., Bhutta, Z. A., Borrazzo, J., Claeson, M., Doherty, T., El-Jardali, F., George, A. S., Gichaga, A., Gram, L., Hipgrave, D. B., Kwamie, A., Meng, Q., Mercer, R., ... Costello, A. (2020). After COVID-19, a future for the world's children? The Lancet, 396(10247), 298-300. https:// doi.org/10.1016/S0140-6736(20)31481-1

Dayal, H. C., \& Tiko, L. (2020). When are we going to have the real school? A case study of early childhood education and care teachers' experiences surrounding education during the COVID-19 pandemic. Australasian Journal of Early Childhood, 45(4), 336347. https:// doi.org/10.1177/1836939120966085

Eames, K. T. D., Tilston, N. L., White, P. J., Adams, E., \& Edmunds, W. J. (2010). The impact of illness and the impact of school closure on social contact patterns. Health Technology Assessment, 14(34), 267-312. https://doi.org/10.3310/hta14340-04

Fitri, M., \& Abdul Latif, M. (2021). Adaptive Learning for Early Childhood Education during the COVID-19 Pandemic in Aceh Jaya District: Online vs. Offline. Al-Athfal: Jurnal Pendidikan Anak, 7(1), 27-38. https://doi.org/10.14421/al-athfal.2021.71-03

Kemdikbud RI. (2020). Panduan Pembelajaran Jarak Jauh. Kementrian Pendidikan Dan Kebudayaan, 021, 28. https://bersamahadapikorona.kemdikbud.go.id/panduanpembelajaran-jarak-jauh/

Mendikbud. (2020). Surat Edaran Menteri Pendidikan Dan Kebudayaan Nomor 4 Tahun 2020 Tentang Pelaksanaan Kebijakan Pendidikan Dalam Masa Darurat Penyebaran Coronavirus Disease (Covid-19). Human Relations, 3(1), 1-8.

Meriana, T., \& Tambunan, W. (2021). Evaluasi Persiapan Sekolah Tatap Muka Di Tkk Kanaan $\begin{array}{llll}\text { Jakarta. Jurnal Manajemen } & \text { Pendidikan, }\end{array}$ https://doi.org/10.33541/jmp.v10i1.3260

Misirli, O., \& Ergulec, F. (2021). Emergency remote teaching during the COVID-19 pandemic: Parents experiences and perspectives. Education and Information Technologies, 0123456789. https://doi.org/10.1007/s10639-021-10520-4

Munro, A. P. S., \& Faust, S. N. (2021). Addendum to: Children are not COVID-19 super spreaders: Time to go back to school. Archives of Disease in Childhood, 106(2), 19-20. https://doi.org/10.1136/archdischild-2020-319908

Nahdi, K., Ramdhani, S., Yuliatin, R. R., \& Hadi, Y. A. (2020). Implementasi Pembelajaran pada Masa Lockdown bagi Lembaga PAUD di Kabupaten Lombok Timur. Jurnal Obsesi : Jurnal Pendidikan Anak Usia Dini, 5(1), 177. https:/ / doi.org/10.31004/obsesi.v5i1.529

Nurdin, N., \& Anhusadar, L. (2021). Efektivitas Pembelajaran Online Pendidik PAUD di Tengah Pandemi Covid 19. Jurnal Obsesi : Jurnal Pendidikan Anak Usia Dini, 5(1), 686. https://doi.org/10.31004/obsesi.v5i1.699

Pacheco, J. A. (2020). The "new normal" in education. Prospects, 0123456789. https://doi.org/10.1007/s11125-020-09521-x

Putra, U. S. (2014). Metode Penelitian: Kuantitatif, Kualitatif, dan Tindakan Bandung: PT. Refika Aditama.

Rasmitadila, Aliyyah, R. R., Rachmadtullah, R., Samsudin, A., Syaodih, E., Nurtanto, M., \& Tambunan, A. R. S. (2020). The perceptions of primary school teachers of online learning during the covid-19 pandemic period: A case study in Indonesia. Journal of Ethnic and Cultural Studies, 7(2), 90-109. https:/ / doi.org/10.29333/ejecs/388

Satrianingrum, A. P., \& Prasetyo, I. (2021). Persepsi Guru Dampak Pandemi Covid-19 terhadap Pelaksanaan Pembelajaran Daring di PAUD. Jurnal Obsesi : Jurnal Pendidikan Anak Usia Dini, 5(1), 633. https://doi.org/10.31004/obsesi.v5i1.574

Shen, K., Yang, Y., Wang, T., Zhao, D., Jiang, Y., Jin, R., Zheng, Y., Xu, B., Xie, Z., Lin, L., Shang, Y., Lu, X., Shu, S., Bai, Y., Deng, J., Lu, M., Ye, L., Wang, X., Wang, Y., \& Gao, L. (2020). 
Diagnosis, treatment, and prevention of 2019 novel coronavirus infection in children: experts' consensus statement. World Journal of Pediatrics, 16(3), 223-231. https:// doi.org/10.1007/s12519-020-00343-7

Sparrow, R., Dartanto, T., \& Hartwig, R. (2020). Indonesia Under the New Normal: Challenges and the Way Ahead. Bulletin of Indonesian Economic Studies, 56(3), 269-299. https://doi.org/10.1080/00074918.2020.1854079

Spaull, N. (2020). COVID-19 and schooling in South Africa: Who should go back to school first? Prospects, 0123456789. https:// doi.org/10.1007/s11125-020-09470-5

Sugiyono, S. (2019). Metode penelitian kuantitatif dan kualitatif dan R\&D. Alfabeta Bandung. Supriyanto, A., \& Rozaq, dkk. (2021). Uji Coba Persiapan Pembelajaran Tatap Muka Masa Normal Baru PAUD " Tunas Bangsa " Semarang. Jurnal Pengabdian Pada Masyarakat, 6(3), 753-763.

Tanuwijaya, N. S., \& Tambunan, W. (2021). Alternatif Solusi Model Pembelajaran Untuk Mengatasi Resiko Penurunan Capaian Belajar Dalam Pembelajaran Tatap Muka Terbatas Di Masa Pandemic Covid 19. Jurnal Manajemen Pendidikan, 10(2), 80-90. https://doi.org/10.33541/jmp.v10i2.3272

Viner, R. M., Russell, S. J., Croker, H., Packer, J., Ward, J., Stansfield, C., Mytton, O., Bonell, C., \& Booy, R. (2020). School closure and management practices during coronavirus outbreaks including COVID-19: a rapid systematic review. The Lancet Child and Adolescent Health, 4(5), 397-404. https:// doi.org/10.1016/S2352-4642(20)30095-X

Wardani, A., \& Ayriza, Y. (2021). Analisis Kendala Orang Tua dalam Mendampingi Anak Belajar di Rumah Pada Masa Pandemi Covid-19. Jurnal Obsesi : Jurnal Pendidikan Anak Usia Dini, 5(1), 772. https:// doi.org/10.31004/obsesi.v5i1.705

Wulandari, H., \& Purwanta, E. (2021). Pencapaian Perkembangan Anak Usia Dini di Taman Kanak-kanak selama Pembelajaran Daring di Masa Pandemi Covid-19. Jurnal Obsesi : Jurnal Pendidikan Anak Usia Dini, 5(1), 452. https:// doi.org/10.31004/obsesi.v5i1.626

Zhang, J., Litvinova, M., Liang, Y., Wang, Y., Wang, W., Zhao, S., Wu, Q., Merler, S., Viboud, C., Vespignani, A., Ajelli, M., \& Yu, H. (2020). Changes in contact patterns shape the dynamics of the COVID-19 outbreak in China. Science, 368(6498), 1481-1486. https://doi.org/10.1126/science.abb8001 